\title{
ДУХОВНО-ЦІННІСНИЙ ЗМІСТ НАЦІОНАЛЬНОї СВІДОМОСТІ
}

\begin{abstract}
О.А. Моргун
Проблема формування національної свідомості українського народу розробляється вітчизняними дослідниками переважно в площині національно-політичної і державницької ідентифікації українського суспільства в процесі демократичних перетворень. Це питання традиційно досліджується у соціополітичному аспекті на теоретико-методологічному підгрунті політичної історії та сучасного націогенезу українського суспільства, на засадах політико-демократичної трансформації в напрямку створення національної держави європейського зразка. Зарубіжні дослідження цієї проблеми більш базуються на твердженнях соціоетнічної ідентичності національних спільнот, а національна свідомість ідентифікується на соціокультурних, соціоекономічних, соціополітичних та ідеологічних методологічних засадах. Ці концептуальні розробки базуються на теоретичних конструкціях «модернових націй», що виникають за межами загального культурно-історичного процесу і не мають спільного коріння зі «старими» націями, або поривають 3 ними. На наш погляд, соціофілософський аналіз світоглядних трансформацій національної свідомості відкриває додаткові перспективи вивчення етногенетичних особливостей процесу націотворення з духовно-ціннісних культурокодів життєдіяльності протоукраїнської спільноти.

Перш за все необхідно відокремити ціннісне життєрозуміння у формі позитивно-оптимістичного ставлення до навколишнього світу. Це-«антистраждальницьке» сприйняття дійсності (як альтернативне «стражданню» в будизмі), «антирятівне» ставлення до життя (бо від земносвіту не треба «рятуватись» за християнською ідеологією, а «відати» його), «антипокірлива» дієвість виявлення стоїчної «волі до життя» за власних сил (а не за волі тих чи інших пророків). За В. Віндельбандом, «життєрозуміння» являє собою виключно оптимістичне ставлення до світу;
\end{abstract}

Актуальні проблеми духовності

(Відп. ред.: Я.В. Шрамко)

Кривий Ріг (2005), 397-402 
життя, як процес розвитку, є сукупністю всіх благ і рух вперед до більшої необхідної дійсності: підсилення і розповсюдження життя є законом в такій же моральній, як і природній» $[1$, с. 276]. В житті центральне місце займають реальні цінності, а не абстрактні істини i, за Г. Ріккертом, для людей більш важлива «цінність істини», а не «чиста істина», бо 3 першою істиною люди живуть «вітально» («життям вітальним»), «навчились жити в ній» як в «живій істині» («живому житті»), «ради істини». Це співвідношення почало стверджуватися ще з часів Давної Греції (а ведо-когнітивно ствердилося ще в прадавньому арійстві), і «люди... почали досліджувати не для того, щоб жити, а жити для того, щоб досліджувати» [2, с. 195-196]. Є. Дюрінг надає життєбаченню вже повністю антирелігійний і матеріалістичний характер і «цінності життя» репрезентує в «філософії дійсності» [3, с.45-62]. Але Є.Гартман зводить соціофілософське дослідження життя на тлі культури до різновидів «позитивістського позитивізму» $\mathrm{i}$ до «метафізичного перетворення проблеми». Ціннісне життєбачення і оптимістичну «волю до життя» він трансформував так, що найвища «нерозумна воля зробила одного разу хибний крок, який був у виявленні себе у значенні життя і дійсності». Але «життєвий процес одержав розумний зміст у тому, що шляхом свого постійного розвитку найглибший сенс якого зводиться до бачення нерозуміння „волі до життя", привів до заперечення акту виникнення світу, до спокутування волі від її злощасного здійснення» [3, с. 45-62].

Отже, стає більш зрозумілим, чому оптимістичний світогляд наших предків і їх бачення життя було позарелігійним, антисхоластичним. Справа в тому, що їх життєдіяльність була безпосередньо-практичною «теорією пізнання реальної діалектики», яка чітко розрізняла «непорівняльність між логічним мисленням і протирічною реальністю» [3, с. 484]. Тобто, ціннісне світобачення - це, вочевидь, природна реальна «діалектика життя», «жива діалектика» в її оптимістичному спрямуванні і життєствердженні.

Інший аспект феномену національної сідомості задає її «ведокогнітивна означеність» в сенсорно-ейдетичних (візіонерських) «картинах світу». Споглядальне ставлення до світу веде до міфотворення і в прадавньому і в сьогоденному аспектах. Відомий французький філософ-структураліст Р.Барт показував, що міф-це «святкова вітрина само-собою-зрозумілого» або як «лжеочевидність». Якщо соціально «розкрити» потаємний «ідеологічний обман» цих «святкових вітрин» серед «псевдоочевидностей поняття міфу» в сучасному зрізі, - то це ж більше як «загальна семіологія буржуазного світу» (що хоче більше «споглядати», ніж «бачити»). Якщо онтологічно розглянути міф в сприйнятті, як «це наша особиста реальність», то можна побачити, що «люди щосекундно плутають Природу і Історію» $[4$, с. 46]. А в позитивно-гносеологічному аспекті«міф-це ко- 
мунікативна система», «один із способів означення», «міф-це форма», в якій переноситься «предмет повідомлення» $\mathrm{i}$ «те, як про нього повідомляється, можна встановити формальні кордони міфа, субстанціональних же кордонів він не має». Тобто в гносеологічному означенні «міф-це слово», але особливе, бо в цьому слові - міфі передається «сугестійна сила світу». I ця «сила впливу безмежна», і тому слово - міф теж має «сугестійну силу» і впливає на людей силою своїх ейдентично-образних і смислових значень [4, с. 72$]$.

Але треба мати на увазі, що поняття «слово», «міф», «ведичність», мають різні означення. «Первозданне слово» пов'язане, за А.А. Потебнею, 3 «живим уявленням», яке безпосередньо розглядається разом зі своїм одним значенням. А міф, пов'язаний «метафористичним уподібненням» 3 кількома значеннями, має «поетичний смисл», бо «міф є найдавніша поезія» [5, с. 256]. Зоряне небо, яке «людина спочатку усвідомлює ... під образом очей небес», людини, потім міфологізується в образі-міфологемі про «тисячоокий, невсипний нічний страж - Аргус». Тобто, міфи швидко втрачають первинне символічне значення і починають «розумітись буквально», і це $\epsilon$ «нездатність людини втриматись на тій висоті думки, на якій вона без будь-яких зусиль зі свого боку опинилася спочатку [5, c. 257-258].

Далі, слід наголосити на культурогенній смисловій інтенційності національної свідомості, яка намагається зберегти і передати культурокоди прадавньої життєдіяльності в соціальному полісеміотичному середовищі, що підпала під христианізацію на теренах античного слов'янства. В подібній інтенційності доісторичної культуротрансляції і культурної трансмісії знайшла вираження потреба в «трагічному побудуванні», яка за В. Віндельбандом (що наслідував Р. Вагнера і Ф. Ніцше), була репрезентована як устремління-потяг «до нової вищої культури, до більш гордого роду, що володіє сміливою волею, скерованою до страхітливого, волею, що звитяжно руйнує вузість теперішнього життя Духу» [1, с.486]. Тобто в подібній інтенційності зберігається традиційна «спрямованість на об'єкт», «націленість на об'єкт» чи на «іманентну об'єктність», що є «феноменологічним рухом» до об'єкту («феноменологічна інтенційність»). У нашому випадку це спрямованість на культуру як «цінно-об'єкт» i «культурооб'єкт», в тому числі і на людину як «самооб'єкт-для-себе» в його суб'єктивності. Тому це спрямованість і на людський дух, інтроєцировану духовність, що іманентна суб'єкту, на його свідомість і самосвідомість, на феноменологічне пізнання духу [6, с. 67-68].

Особливість національної культурогенної інтенційності і полягає саме в її націленості не тільки на об'єкт, але й на суб'єкт, на його дух, з метою «самопізнання духу» і окремо - на саме ведичне знання як «епістеме» («епістемологія» ведичного Духа), на пізнавальні можливості свідомості 
і самосвідомості за відомою феноменологічною формулою «свідомість за своєю інтенціальною природою є завжди свідомість чогось...» I в цих виявлених і розкритих смислах і значеннях цінностей культури («істин культури») можна простежити інтенційне устремління до збереження, передачі-трансляції і зв'язку-трансмісії монодуховності і космоцентричності прадавнього ведичного світобачення у «правильному» і «вірному слові», в «правому слові», в «православній вірі» як каноні, в якій ще не було християнської ідеології «мучеництва» та «спасіння» і політичного православ'я.

Ця передумова практично реалізується за часів Київської Русі, коли «природне правослов'я» трансформується в «соціальне православ'я візантійського типу і стверджується у «візантійському християнстві» Другого Риму. Подібна (хоча вже змінена) ціннісна означеність комунікативносмислової свідомості української нації чітко простежується і зараз в культурогенній інтенції до створення інтегральної східноєвропейської культури. В цьому може і полягає «історична місія» українського народу, яку не могли реалізувати древні греки, бо складу їх мислення була властива «антиісторична тенденція». 3 цієї історичної тенденції можна побачити ще одну культурно-історичну складову національної суспільної свідомості.

Важливу роль відіграє, на наш погляд, генетична соцієтальність ціннісного життєрозуміння і світобачення в інтегральній природній впорядкованості. Духовна цільність обумовлює і соцієтальну цілісність в інтегративній якості «соцієтальності», а більш ширше - у вигляді інституту етнонаціональної суспільної солідарності. В ньому духовні і соціогосподарські імперативи стоять на першому плані, а політичні та ідеологічні складові нормативно підпорядковуються першим. За Г.Парсонсом, «ядро» соцієтальної спільноти створюється «системою культури», «культурною якістю суспільства» в значенні «культурної легітимізації нормативного порядку», що саморегулююче «діє через інституціоналізацію системи цінностей, яка $є$ складовою частиною і соцієтальної і культурної системи $[7$, с. 26]. Соцієтальність, з одного боку, конкретна, - «плюралізм ролей і статусів особистості, особистих мотивів, насамперед, до соціальної престижницької діяльності в стратифікаційній системі», впорядкованість яких і породжує «контактні відношення колективної взаємодії солідарності», «лояльність по відношенню до соцієнтального колективу». А, з іншого боку, - «засади культурної легітимізації трансцедентно по відношенню до конкретного» на «соцієтальному рівні» суспільних «ціннісних прихильностей» [7, с. 25, 27].

В сучасній соціологічній теорії соцієтальність розглядається як те, що виконує «функцію інтеграції соцієтальної спільноти..., координуючи різні елементи суспільства». Згідно з соціологією знання Н. Лумана, су- 
спільство, якщо воно нормативно впорядковане як соціальна система (в системі культури), «включає всі інші соцієтальні системи «в якості» функціональних систем» (логіка речення не простежується). У Т. Парсонса це функціональні системи (що інтегровані в підсистеми) соціальної науки, законодавства. Якщо це мати на увазі, то тоді «генетичній соцієтальності» в національній свідомості передують життєстверджуючі цінності, когнітивні знання, екзистенціальне господарство, генералізуючі моральні настанови, природне право, соціокультурна владність. I все це постає у «взаємодії людей як суб'єктів спільного або колективного життя» в їх узгодженості, солідарності, взаємозваженості. 3 цього виходить, що наші предки добре знали генетичні соціокоди соціальної самоорганізації, i їх соціальна культура дозволяла кілька тисячоліть обходитись без політичної складової своєї життєдіяльності.

Люди, переходячи від суто природного існування до соціального буття, опановують поняття «моральність» через різні «моральні почуття» («моральні емоції», «моральні сентименти», загалом, «моральну психологію»), які вже в соціоприродному плані формують «чуття справедливості» [8, с. 658-663]. Воно виникає у вигляді «морального ставлення», моральних принципів вже в філософській інтерпретації «початкової позиції», «первісної позиції» (соціально-природної), в якій «інтуїтивна ідея справедливості, як чесності, доводиться до уявлення першопринципів справедливості як таких, що самі $є$ предметом первісної угоди у доречно визначеній початковій ситуації [8, с. 175-176]. Це вже суто «соціальні позиції, що $\epsilon$ «релевантними першопринципами» моральності, «релевантні соціальні позиції» морально узгодженого життя. 3 цього історичного моменту первісна людська спільнота перетворюється на «добре організоване суспільство, як таке, що його призначенням $є$ сприяння благу його членів та дійове регулювання громадських концепцій справедливості» [8, с. 143].

На нашу думку, сьогодні все більшої актуальності набуває філософсько-світоглядний пошук нового світобачення і зміна парадигми «Виклик-і-Відповідь» на «Заклик-і-Відгук» («добрий Відгук на добрі Вісті») 3 метою позитивного сприймання майбутнього XXI ст. Для здійснення цього повороту необхідно вірно спрогнозувати головні закономірності розвитку суспільного буття «від зворотнього» - від знання тенденцій (закономірностей) розвитку суспільної свідомості з прадавнього минулого в прогнозі та інноваційному випередженні на майбутнє. В історико-філософському сенсі мова йде про культурогенну світоглядну трансформацію на культурокодах інноваційних смислозначень духовно-когнітивних цінностей. Ї̈̈ результатом буде творення історично нової духовно-практичної суспільної свідомості на національному терені, яка набагато випередить суспільне буття, що тяжіє застарілими стереотипами і потребує модернізації, оновлення та духовного перевтілення у візіонерських картинах 
конструктивного світобачення. Тобто, спочатку нам потрібно побудувати свого роду новий «духовний храм» в людській свідомості, а потім здійснити предметно-творчу реалізацію цього проекту в більш гармонійному i справедливому Бутті. Для цього й необхідно перш за все встановити соціоісторичні закономірності формування суспільної свідомості українського народу.

\section{1 Бібліографія}

[1] Виндельбанд В. История новой философии. - М.: Канон-Прес, 2000.

[2] Риккерт Г. Философия жизни. - Минск: Харвест; М.: АСТ, 2000.

[3] Дюринг Е. Ценность жизни. - Минск: Харвест; М.: АСТ, 2000.

[4] Барт Р. Избранные работы.-М.: Прогресс, 1989.

[5] Потебня А.А. Слово и миф.-М.: Правда, 1989.

[6] Федорика Д. Інтернаціональність і самосвідомість // Досвід людської особи. Нарис з філософської антропології. - Львів: Свічадо, 2000.

[7] Парсонс T. Система модернизированного общества. - М.: АспектПресc, 19 .

[8] Ролз Дж. Теорія справедливості. - К.: Основи, 2001. 